\title{
3
}

\section{Education and Elderly Care in Denmark, Norway and Sweden: National Policies and Legal Frameworks for Private Providers}

\author{
Signe Bock Segaard and Jo Saglie
}

\section{Introduction}

As a starting point for the case studies of the following chapters, this chapter presents the national context for municipal welfare services: primary and lower secondary education, and institution-based elderly care. We aim to shed light on the national political, legal and institutional framework within which local welfare services are provided, and how different frameworks may have consequences for the welfare mix.

To what extent is the national context in Denmark, Norway and Sweden different? In the literature on 'welfare regimes', there is considerable agreement that the three countries can be placed within the 'Nordic model' (Ervasti et al. 2008, 5). This points to several similarities in the organisation of the welfare state. Welfare services are, to a great

\footnotetext{
S.B. Segaard $(\bowtie) \cdot$ J. Saglie

Institute for Social Research, Oslo, Norway

e-mail: sbs@socialresearch.no

J. Saglie

e-mail: jo.saglie@socialresearch.no

(C) The Author(s) 2017

K.H. Sivesind and J. Saglie (eds.), Promoting Active Citizenship,

DOI 10.1007/978-3-319-55381-8_3
} 
extent, publicly financed and provided on the basis of universal rights, and the municipalities play a crucial role in the implementation of these services. That is also to say that private providers of publicly financed welfare services operate within a context characterised by mainly public providers. Furthermore, during recent decades, promoting active citizenship in public service has been and still is an overall aim in all three Scandinavian countries. This has implied a stronger emphasis on more user involvement and empowerment as well as on developing a broader range of services and creating genuine user choice between alternative service providers. However, and as we will show in this chapter, the tools of government for promoting this aim have been different in the three countries. Another common element is that public-sector procurement is regulated by an EU Directive that all three countries have implemented, even though the implementation has to some extent taken place in different ways and at different points in time (Segaard 2015). On the one hand, an international perspective makes it clear that the Scandinavian welfare states share many features - which separate them from other countries. On the other hand, there are also considerable differences between the Scandinavian countries themselves, and these differences have become more pronounced during recent decades. As the previous chapter shows, the differences apply to the mix of public, nonprofit and for-profit services within education and elderly care. While the extent of private nonprofit providers is relatively large in Denmark, for-profit service providers play a more significant role in Sweden. In Norway, the roles of both of these types of private actors are in fact comparatively modest. However, in an international context, the sizes of the nonprofit and for-profit sectors in the Scandinavian countries are still relatively small.

The starting point is thus that some fundamental differences in the organisation of welfare services exist between the three countries, in spite of the overall similarities. This chapter aims to explore one possible explanation for this: the national policy, legal and institutional framework for private service providers. In exploring this, we develop and use three government models as a framework for comparison of the national policies on private-both nonprofit and for-profit-actors in service production. We make a distinction between direct, indirect and disconnected government. The underlying question is whether variations in 
such national government models can explain the observed differences in the national 'welfare mix' of public, nonprofit and for-profit services within both education and elderly care. Regardless of the answer, the next question is naturally whether some underlying factors affect differences in national policy models as well as differences in the actual welfare mix. There is no room for a comprehensive discussion of such factors in this chapter, but politics as a driving factor will be briefly discussed in the concluding section.

\section{Three Government Models}

As an analytical framework to explore and capture national welfare policy and legislation for private providers of publicly financed elderly care and education, we develop three ideal government models of how publicly funded welfare services might be organised: (1) direct government, (2) indirect government and (3) disconnected government. The models, summarised in Table 3.1, reflect different policies for public-private collaboration on public welfare production and thereby represent different approaches to the welfare mix on a more general level. The policies might manifest in contracts and institutional systems for approval and supervision, for example. The way supervision is organised (self-evaluation or control by national authorities, general or detailed criteria) is significant for understanding the freedom of discretion that each actor has.

Table 3.1 Ideal models of government in public welfare production

\begin{tabular}{lll}
\hline & Actors & Discretion \\
\hline $\begin{array}{l}\text { Direct government } \\
\text { Pure public organisation } \\
\text { Contracting }\end{array}$ & $\begin{array}{l}\text { Public } \\
\text { Public/Private }\end{array}$ & $\begin{array}{l}\text { Public } \\
\text { Public }\end{array}$ \\
$\begin{array}{l}\text { Indirect government } \\
\text { Collaborative governance }\end{array}$ & Public/Private & Public/Private \\
$\begin{array}{l}\text { Fisconnected government } \\
\text { Free market-based organisation }\end{array}$ & Private & Private \\
Philanthropy & Private & Private \\
\hline
\end{tabular}

The typology is developed by the authors based on Donahue and Zeckhauser (2006, 496ff). 
Each of the government models reflects a specific solution for organisation and interaction between public and private actors-nonprofit as well as for-profit-in the production of welfare services. The solutions are different with regard to where discretionary power over central aspects of service production is allocated.

We distinguish between three types of discretionary power. Production discretion involves the competence and possibility to specify the goals and means of the welfare service in question. Payoff discretion refers to the freedom to decide how the final outcome in monetary terms should be used and distributed by the private service provider. This also concerns the opportunity for the provider to transfer profits to owners and investors. Moreover, payoff discretion involves defining the end result: Should it be perceived as good or bad? The organisation of supervision and control may be significant in this respect. The service provider will have a larger extent of payoff discretion if supervision is based on self-evaluation with general evaluation criteria, compared with supervision carried out by a national authority and based on detailed criteria. Finally, preference discretion refers to the normative view and understanding of the welfare service and the mission behind it. Preferences and underlying values may be related to pedagogy, professional ethics, beliefs, philosophy or religious faith. Discretion in service production therefore involves a kind of freedom to define the public interest behind the service provision (Donahue and Zeckhauser 2006, 514).

Looking at how discretion is approached in the three government models, the public sector is assumed to have full discretionary power in the direct government model, regardless of whether a purely public organisation or contracting is chosen. In the latter case, the public principal commissions the work and governs through monopoly of discretion with regard to production, payoff and preferences. The monopoly will manifest in the contract, which will appear as a means for control and performance measuring (Phillips and Smith 2011). In this context, 'contracting' does not refer to the existence of a written contract, but rather interaction between the authorities and a private actor which is solely based on the simple delegation of tasks without any freedom of discretion. 
In the disconnected government model, freedom of discretion is assumed to be fully handed over to the nonpublic service provider through the free market or pure philanthropy. The model of the free market assumes that government and organisation of welfare services take place through users' freedom of choice and competition between private service providers. The difference between free market and pure philanthropy is not related to discretion, but to the kind of private actors involved. In pure philanthropy, private actors are nonprofit, whereas a pure market model includes only for-profit actors. In real life, however, the picture is more mixed.

The indirect government category in the model comprises collaborative governance. ${ }^{1}$ This refers to collaboration between a public principal and a private-for-profit or nonprofit — service provider characterised by self-regulation within a specific political and institutional framework (Sørensen and Torfing 2008, 10). Moreover, with regard to discretion, we consider collaborative governance to be ' $[\mathrm{t}]$ he murky middle ground, in which both parties exercise discretion' (Donahue and Zeckhauser $2006,514)$. The empirical question is how and to what extent discretion is divided when it comes to 'defining not only the means by which a goal is achieved but the details of the goal itself (Donahue and Zeckhauser 2006, 497). In line with Donahue and Zeckhauser, we underline two considerations that are important for how discretion is shared between actors. First, a consideration of democracy requires that 'a large share of discretion must rest with a player who is answerable to the public at large' $(2006,509)$. At the same time, both the public principal and the nonpublic provider must have some share of discretion-otherwise, the relationship would not be collaborative $(2006,509)$.

The literature on governance points to 'relational contracting' as a distinguishing feature of collaborative governance:

[a]lthough contracts may continue to be important policy tools, they would be more than a means of control over the purchase of service (...). The focus on strengthening relationships should be evidenced by more relational contracting which puts an emphasis on working toward common goals, promoting communication and flexibility, and developing trust. (Phillips and Smith 2011, 5) 
Public-private interaction based on the idea of collaborative governance is often praised for its flexibility and capacity; but, as Donahue and Zeckhauser $(2006,497)$ stated, 'at the price of more ambiguous lines of authority and far greater strategic complexity'.

Table 3.1 presents the models of government in welfare production as ideal types. This is appropriate as an analytic framework when the intention is to identify similarities and differences; however, we are aware that it does not necessarily represent the whole empirical reality. The pure models may be combined with each other to create a more complex regime of government in welfare production. For instance, such a layered government may combine the idea of free user choice with elements from the (in)direct model when the authorities, through pure public organisation, contracting or collaboration with more than one service provider, facilitate the free choice of the user. Here, layered government implies organising the welfare mix through two steps: first, the selection of providers by the authority and then, in the next step, selection by individual users.

Our approach to and understanding of the welfare mix is (partly) based on the assumption that government models are chosen and developed over time in light of political visions and ideologies. This understanding is in accordance with Phillips and Smith's (2011) explanation of why private service providers - nonprofit as well as for-profithave become more involved in public welfare production. They remind us that it is not the type of welfare state that explains the development towards more or less relational governance and involvement by the third sector, but rather political visions and the ability to collaborate (2011, 23-24):

.... vasion of the role of the third sector that sees it as more than a social safety net or delivery agent of services, but that advances the value of the sector for democracy and citizenship and/or economic development. The vision then needs to be driven by strong political leadership. A connection to democratization or economic development is evident in all cases in which major reform has occurred (...). However, it is also clear that such a reform project has to be mutual and that neither government nor the third sector can drive it alone. 
The remainder of this chapter comprises three sections. Each section discusses factors at the national level that may affect the use of nonpublic actors in local service production within primary and lower secondary education, and institution-based elderly care. We limit the analysis to the state as of mid-2015. First, in the following section, we briefly outline the EU Public Procurement Directive (Directive 2004/18/EC) that has been in effect the last decade and how national legislation in the three countries is related to it. To fully understand the national framework, it is necessary to take into account that EU policies set limits for the national legal framework. Norway, Denmark and Sweden are obliged to implement EU directives. Regarding outsourcing of welfare services, the EU Public Procurement Directive is especially relevant. Second, we address national policies on schools and elderly care. Within each country, national policy standards are set by means of various policy documents-legislation, instructions, guidelines, etc. Based on the analysis of these national policy documents, we compare and discuss national policies which direct how contracts are awarded and coordinated within these municipal welfare services. Finally, in the concluding section, we summarise our findings and discuss underlying political factors that may explain national policies as well as the welfare mix.

\section{The EU Public Procurement Directive and Its Implementation at the National Level}

In the Scandinavian countries, the use of public contracts with private service, work and supply providers is generally regulated by national legislation and instructions, but also by EU directives. Even though Norway is not a member of the EU, it is bound by EU directives through the EEA agreement (European Economic Area). The EU Directive on the coordination of procedures for the award of public works contracts, public supply contracts and public service contracts (Directive 2004/18/EC) has in the last decade served as an important backdrop for national policies on the use of nonpublic actors in the production of welfare services, when 
these services are produced on the basis of contracts between municipalities and providers. It is this directive that is the focus of this section.

The Directive (with attachments) specifies the process and procedures for public procurements based on written agreements between a contracting public authority at the state, regional or local level and an economic operator. ${ }^{2}$ The overall principles for the award of public contracts are that the processes must be based on transparency and equal and non-discriminatory treatment of all operators. ${ }^{3}$ One implication of these criteria is that a prior information notice with information about the 'buyer profile' must be published and that the information must not only be given to selected operators (see Chapter VI of the Directive). Moreover, the Directive stresses the standardisation of processes and the specification of clear requirements and expectations in the contracts. However, the Directive also defines several categories for public procurement procedures, each with different implications for which kind of economic operators may submit a tender. The document distinguishes between open procedures, restricted procedures and negotiated procedures (Article 1(11)): ${ }^{4}$

(a) 'Open procedures' means those procedures whereby any interested economic operator may submit a tender.

(b) 'Restricted procedures' means those procedures in which any economic operator may request to participate and whereby only those economic operators invited by the contracting authority may submit a tender.

(c) 'Negotiated procedures' means those procedures whereby the contracting authorities consult the economic operators of their choice and negotiate the terms of contract with one or more of these.

In addition to these procedures, the Directive defines a procedure entitled competitive dialogue (Article $1(11)(\mathrm{c})$ ) that is meant to be used when a public contract is 'particularly complex'. This implies that the contracting authority is unable to specify the technical, legal or financial conditions and requirements without dialogue with the candidates admitted to that procedure. 
Whether the Public Procurement Directive comes into operation depends on the value of the contract (cf. the threshold amounts defined in the Directive) and the type of contract. Regarding the latter, the Directive defines some specific exceptions. These exceptions include service concessions (see Chapter 2, Sect. 3, Article 17) which are of specific relevance for welfare services. A service concession implies that (CURIA n. d.) $)^{5}$ :

...the consideration for the provision of services consists in the right to exploit the service, either alone, or together with payment.

...the service supplier takes the risk of operating the services in question (...) In order to find that there is a service concession, it is necessary to establish whether the agreed method of remuneration takes the form of the right of the service provider to exploit the service and entails it taking the risk of operating the service in question. While that risk may, at the outset, be very limited, it is necessary for classification as a service concession that the contracting authority transfers to the concession holder all or, at least, a significant share of the risk which it faces.

As the quotation states, the decisive criteria are that the service provider (concession holder) (also) runs a real risk by operating the right of the service in question. In other words, a service concession holder administers the right to provide a service to users.

\section{National Implementation of the EU Public Procurement Directive}

Basically, contract-based public procurement is regulated by a common EU Directive in Norway, Denmark and Sweden. However, while implementing the Directive, each Scandinavian country has left its own distinctive mark on the regulation of public procurement within its own borders. Here we will describe some of the country-specific conditions at the national legal level that have implications for the two welfare services, institution-based elderly care and primary and lower secondary education, and more specifically, the scope for nonprofit service providers. 
The EU Directive on public procurement was implemented in Norwegian legislation through the Public Procurement Act in 1992 (Norwegian: Lov om offentlige anskaffelser m.v.). This act and its regulations have been revised several times since then (Ødegård 2006, Segaard 2015). ${ }^{6}$ In addition, some other kinds of public procurements outside the scope of the Directive have been regulated in Norway for years. This is the case for service concessions (Udbudsrådet 2012, 19-20), procurement with lower threshold amounts than those defined by the EU, and 'B' (non-priority) services. Non-priority services include, for example, health and social services. In general, it is stated that all public procurements must fulfil the requirements of non-discrimination, transparency and predictability according to $\$ 5$ in LOV-1999-07-16-69 (The Norwegian Government 2006). The Norwegian government emphasises that it is always possible to negotiate with the providers. In this way, national regulations are considered more flexible than the Directive (Konkurransepolitisk avdeling 2008).

Regarding opportunities for nonprofit organisations to provide welfare services within the health and social sector, the Norwegian government implemented an exception to the rules on public procurements in 2004 (FAD 2013). This exception went out of force when Norway implemented new rules on public procurements in June 2016 (Directive 2014/ $24 / \mathrm{EU})$. At the time of writing, the majority in the Norwegian Parliament still want to support the nonprofit sector and be able to give priority to nonprofit service providers within the health and social sector. However, it is uncertain how this will be carried out. The Norwegian government is in the process of clarifying whether it is possible to maintain the exception through a so-called 'adaptation text' (DIFI 2014; Sejersted 2014). Nevertheless, the exception was important for the regulation of the welfare mix in Norway because it meant that national and local authorities could choose between negotiating with nonprofit organisations and following the ordinary rules for public procurements (Konkurransepolitisk avdeling 2005). Moreover, the exception implied that the contracting authority did not need to follow Part II of the regulation, including the requirement for national tender announcements in the Norwegian national notification online database for public procurement. It was thus possible to exclude contracts with nonprofit providers from the requirement for competitive 
tendering (Konkurransepolitisk avdeling 2008). However, it was also stressed that the contracting authority ought to pursue competition between nonprofit organisations (Konkurransepolitisk avdeling 2008).

The background for this exception was that competitive tenderingwhere nonprofit actors must compete on equal terms with for-profit actors - was seen to contradict the overall aim of promoting societal engagement and collaboration with nonprofit organisations (FAD 2013, 99; see also Konkurransepolitisk avdeling 2005). Since 2007, the regulations have explicitly stated that in the case of public procurement of health and social services from nonprofit organisations, it is up to the contracting authority to assess whether the whole legislation on public procurement should be followed (Part I-III) or the exception should be used (FAD 2006, 2013). In other words, it is possible to give special treatment to nonprofit health and social service providers in Norway.

The Norwegian regulation of public procurement does not provide a precise definition of 'nonprofit organisation', but it does describe some of its characteristics (FAD 2013, 99ff). Nonprofit organisations are distinguished by volunteering and charitable work; they carry out tasks for society on behalf of public authorities, and their profit, if any, is used for their charitable work. Nonprofit organisations will often, but not necessarily, be organised as foundations (FAD 2006, 87; see also FAD 2013, 99ff).

Denmark implemented the EU Directive through a so-called Executive Order; in other words, a set of rules that expands and supplements an act (Udbudsportalen 2014a; Udbudsrådet 2012). The first Executive Order that implemented the EU Directive on public procurement came into effect on July 1, 1993 (BEK nr 415 af 22/06/1993), while the Executive Order in force in 2015 was implemented in 2011 (BEK nr 712 af 15/06/2011). Moreover, public procurements in Denmark are regulated by the Procurement Act (Danish: Tilbudsloven). ${ }^{7}$ This act comes into effect when the contract value is between 500.000 DKR and the threshold amounts as defined at the EU level. This means that Denmark-like Norway-has expanded the scope of public procurement regulations compared to the minimum requirements defined in the EU Directive. Until 2013, non-priority services, including health and 
social services, were encompassed by the Procurement Act, but this is no longer the case. ${ }^{8}$

Regarding possible exceptions to the EU Directive, the argument based on the so-called 'in-house case law' is emphasised in Danish policy documents. For example, the Konkurrencestyrelsen $(2010,2)$ stated that 'the tasks carried out by self-owning institutions can be characterised as services executed in-house, and are therefore not subject to public procurement regulations' (our translation). Here, 'tasks' refer to a situation where a self-owning institution provides a welfare service (e.g., institution-based elderly care) on behalf of a municipality and the following two criteria are fulfilled (Udbudsportalen 2015, our translation):

- The criterion of contracting entity: The institution mainly carries out tasks for the municipality. If the institution carries out tasks for others, it must be of marginal extent only.

- The criterion of control: The municipality exercises control over the institution, which is similar to the control it exercises over its own departments. This may imply control over budget matters, commercial investments, strategies, etc.

In Sweden, the EU Directive on public procurement was implemented in national legislation in $1995 .^{9}$ Konkurrensverket, which is the inspection authority, stresses that following Swedish regulations on public procurements ensures that EU regulations are fulfilled as well (Konkurrensverket 2014). The relevant Swedish legislation builds mainly on the EU Directive 2004/18/EG. Regarding possible exceptions to the rules on public procurements, Swedish authorities, as with the Danish, refer to the in-house case law-the criterion of contracting entity and the criterion of control-and legal practice from the Court of Justice of the European Union (see Udbudsrådet 2012, 18; The Swedish Riksdag 2012).

Looking at the threshold amounts that determine whether a public procurement is the subject of national legislation, the thresholds are similar in Denmark and Norway but somewhat lower in Sweden (Udbudsrådet 2012, Fig. 2.1). The national threshold amounts defined 
in the national regulations of all three Scandinavian countries are lower than the threshold amount defined in the EU Directive.

Finally, it should be noted that an exception to the rules on public procurements for nonprofit actors parallel to the one in place in Norway does not exist in either Sweden or Denmark (Kronbøl 2015). Moreover, only Norwegian national legislation includes regulations on service concessions (Udbudsrådet 2012, 19-20). However, it is possible for Danish and Swedish authorities (e.g., in a municipality) to sign a contract with a nonprofit service provider without following the complete regulations for public procurements. The reason for this is the in-house case law (see Udbudsrådet 2012, 18; Konkurrencestyrelsen 2010; The Swedish Riksdag 2012).

\section{The Importance of the EU Public Procurement Directive}

Public welfare services are mainly a municipal task in Norway, Denmark and Sweden, and the municipalities have to some extent the power to decide how the services should be organised - with consequences for the welfare mix. Local autonomy and the principle of subsidiarity are traditionally appreciated in Scandinavian local government (Rose 2005, 5760). However, the municipalities do not act in a vacuum, and the EU Public Procurement Directive affects local as well as national policymaking. The fact that municipalities have a certain amount of latitude is nevertheless important to stress.

The EU Directive itself does not exclude any of the three ideal models of government specified in Table 3.1: neither the direct, indirect or disconnected government model for organisation and interaction between public authorities and private service providers. One reason for this is that the Directive is primarily concerned with procedural principles for how contracts should be awarded and on what grounds. However, the descriptions of the different procedures for public procurement (Article 1, 11 (a)-(d)) gives the contracting authority the opportunity to restrict competition at an early stage and invite some, but not all, potential providers (economic operators) to submit a tender. 
Moreover, it is also specified that the character of the service in question may weigh in favour of dialogue or negotiations with selected potential providers. In this kind of dialogue or negotiation, we consider it to be possible to influence the allocation of discretionary power, which is a key element of the government models in Table 3.1. To what extent dialogue or negotiations are relevant is an empirical question in each case. Finally, the Directive allows exceptions to the rules on public procurements and defines cases in which the Directive does not go into effect. If a public authority chooses to make use of the exceptions to the rules or organise its production of welfare services in a way that is outside the scope of the Directive, then that authority has a great opportunity to influence the welfare mix. In other words, we will emphasise that the common European policy for public procurements does not prevent different ways of organising welfare services in EU member states.

The national welfare mix is thus also a question of political choice, will and cultural traditions, and the EU Directive makes it possible to take these aspects into account. The openness to diversity is reflected in the national policies and legal framework for private providers in Scandinavia, as well as in the fact that the three countries to some degree use their freedom of action differently. In general, their national regulations are more restrictive than what the EU Directive requires; for instance, by setting lower threshold amounts for when open calls for tenders are required.

As mentioned above, after the implementation of new rules on public procurement, the Norwegian exception for nonprofit providers is no longer in force. We should nevertheless bear in mind that not only is a revised Directive on public procurement being implemented, but a new EU Directive on the award of concession contracts is being implemented as well (Directive 2014/23/EU). ${ }^{10}$ According to the European Commission, it will be possible to exclude some forms of welfare services from the full application of this Directive, such as when public service production is organised though concession contracts (European Commission 2014). The Directive states: 
[i]t is appropriate to exclude from the full application of this Directive only those services which have a limited cross-border dimension, such as certain social, health, or educational services. Those services are provided within a particular context that varies widely amongst Member States, due to different cultural traditions. (Directive 2014/23/EU, (53) page 10)

Furthermore, the new Directive on the award of concession contracts (Article 17) states that a concession that fulfils what we have previously described as the two criteria of the in-house case law (the criterion of contracting entity and the criterion of control) falls outside the scope of the Directive (see also paragraph 3.2 in SEC (2011) 1169 final). Moreover, the Directive allows EU member states to use discretion in the welfare mix:

Given the importance of the cultural context and the sensitivity of those services, Member States should be given wide discretion to organize the choice of the service providers in the way they consider most appropriate. (Directive 2014/23/EU, (54) page 10)

The Norwegian authorities have raised the issue of the conditions for nonprofit actors - and the possibility of maintaining the exception to the rule for nonprofit actors - after the implementation of the revised Directive on public procurement. However, this appears to have been done without establishing whether alternative solutions for service production exist. The new Directive on concession contracts, the opportunity to set aside the regulations defined in the Directive, and common practice in Denmark and Sweden indicate that such alternatives do indeed exist. It appears that each individual country will still be able to use discretion in organising the welfare mix it considers the most appropriate, in light of its own cultural context. ${ }^{11}$ These national policies are the subject of the following sections. 


\section{National Policies on School and Elderly Care ${ }^{12}$}

\section{Nonpublic Producers of Primary and Lower Secondary Education, ${ }^{13}$}

In this section, we summarise the national private school policies of the three Scandinavian countries, drawing on the analytical government models from Table 3.1: direct, indirect and disconnected government. Based on detailed analysis of national policy documents such as legislation, instructions, and guidelines (see Segaard 2015), we aim to identify some central similarities and differences in the distribution and coordination of 'contracts' in primary and lower secondary education in Denmark, Sweden and Norway.

The public sector traditionally plays the leading role in education in Norway, Denmark and Sweden. A common feature is that the great majority of children in primary and lower secondary education attend a municipal school. There are, however, some variations between the three countries regarding the distribution of children between public and private schools. According to Eurostat (2012, 33), 95.6 percent of Norwegian school children attend a public school, whereas the corresponding figures for Denmark and Sweden are 86.5 and 89.4 percent, respectively. Norway thus has a lower share of children in private schools than in either Denmark or Sweden.

The problem with these figures is that official statistics often do not distinguish between different categories of private schools, such as between for-profit and nonprofit schools. As we shall see, this distinction is crucial when education policies in the three countries are compared. In Sweden, private primary and lower secondary schools that receive public funding can be run on a commercial basis. This is not allowed in Norway and Denmark. Private schools in Sweden are basically fully financed by the public sector, and the schools are not allowed to charge school fees. That is not the case in Denmark and Norway, where private schools are only partly funded by the state. Danish and Norwegian private schools may thus charge school fees-and are in fact expected to do so. In both countries, it is also required that public funding be used exclusively for 
educational purposes. Moreover, in Denmark, private schools are by law required to be run by nonprofit institutions. It is obviously appealing to be a for-profit operator in the Swedish primary education system, where schools are fully financed by the public sector, profits can be paid out to owners, and the authorities have in practice no right to examine the operator's accounts. In other words, Swedish for-profit school owners operate under much freer conditions in economic terms, but are somewhat more restricted in terms of educational content than in either Denmark or Norway.

In all three countries, primary and lower secondary schools fall under the jurisdiction of the municipalities, as the municipalities are obliged to offer education to all children in this age group. Nevertheless, private schooling of children in this age group is subject to an approval system at the national level. A state institution is responsible for approving private schools (the Norwegian Directorate for Education and Training, the Danish Ministry for Children, Education and Gender Equality, and the Swedish Schools Inspectorate). In primary and lower secondary education, nonpublic actors thus apply for the right to run schools, and a national public-sector body gives (or refuses) them this right. This can be regarded as a 'service concession' according to the EU Public Procurement Directive. As mentioned above, this means that the provider is given the right to provide services and runs a real risk in exploiting this right in practice. The argument is that the provider only receives a partial payment from the public-sector body, while the rest is paid by the users, who are free to choose whether they will use this service. Accordingly, we assume that private schools can be said to be outside of the scope of the EU Directive on public procurement. ${ }^{14}$

Contracts for private schools with public funding are awarded on the basis of a national authorisation system in all three countries, which ensures that the schools adhere to national regulations of the organisation and educational content. By means of this approval system, we consider national authorities to exercise indirect government by defining requirements and conditions for approval. Moreover, this approval can be revoked if inspections show that the schools have not adhered to these requirements and conditions. Accordingly, interaction between the authorities and private service providers is formalised in an agreement, 
with more or less detailed criteria for approval. This indicates the extent of formality (cf. Table 3.1).

The extent of national control and discretion given to each actorboth the authorities and the provider-vary substantially between the three countries. The focus of the regulations also differs. Danish private schools appear to enjoy more discretion regarding educational content as well as the values on which they are based. A central element of Danish school policy is that educational content should correspond to the basic values of the school, and that potential users must be informed of this. We suppose that the approval of Danish private schools is to a large extent performed on their own terms. This is evident because the regulations emphasise that the schools should be able to define their own teaching content and methods based on their own basic values and distinctive characters. In Norway, and perhaps even more in Sweden, the national authorities set forth detailed standards for education. Private schools must comply with the standards set for public-sector schools. In other words, we consider national requirements for the content and organisation of teaching to be less strict in Denmark than in Norway and Sweden. Whereas public-sector schools can be perceived as setting a minimum standard for primary and lower secondary education, in Denmark, public-sector schools in Sweden and Norway can be viewed as a template which private schools must follow. The fact that a single act governs both public and private schools in Sweden illustrates this point. In Norway and Denmark, private schools that receive public funding are regulated by a separate act.

In order to obtain a diverse educational system, Danish authorities also give private schools considerable leeway. Danish private schools can reject applicants, even if they have room to admit more pupils. In this way, we believe that a school can cultivate its own distinctive image. The primary and lower secondary school system as a whole can thus become more diverse. In contrast, Swedish and Norwegian private schools generally cannot reject applicants if they have room to admit them. This can be seen as a way to secure free choice for users. In practice, the democratic right of users to free choice can thus undermine distinctive alternatives to public schools and thereby reduce diversity within welfare services that the authorities in principle aim for. This is because the lack of opportunity to 
reject pupils also curtails the exercise of discretion on the part of the provider.

Although some differences exist, the users' right to free choice is a basic entitlement in Norwegian, Swedish and Danish primary and lower secondary education. In light of our analytical framework, this means that the indirect national government is supplemented by a form of disconnected government, because the market - the users, through their individual choices - takes part in shaping the educational system. However, the circumstances under which users can make an informed choice vary between the three countries, at least in terms of national regulations. Danish legislation and regulations, for instance, dictate that schools have a duty to inform users. The content of the information, as well as the channels through which information is conveyed, are fully outlined. Such regulations are largely absent in corresponding Norwegian and Swedish regulations.

Our opinion is that this statutory duty to inform users in Denmark highlights the importance of knowing which options to choose from and the consequences of each choice. Every choice certainly has consequences, especially with respect to the rights and obligations that pupils and their parents agree to accept. Denmark also stands out in this area. Parents of children in Danish private schools are given formal duties and the responsibility to participate in the running of the schools. A group of parents at a private school in question (called the 'circle of parents') is given a formal obligation to supervise the school. More generally, this aspect of what we call collaborative governance is evident in the Danish system for the supervision of private schools. Not only are the parents involved, but also the school itself can choose to assume an important role by means of self-evaluation. This is done on the basis of a template developed by a school association (a national organisation for private schools of a specific type, such as religious, German minority or Waldorf/Steiner education) and approved by the national Board of Supervision. The inclusion of parents and nonprofit organisations in supervising the schools is a striking example of how collaborative governance entails an aspect of self-regulation within a specific political and institutional framework at the national level (see Sørensen and Torfing 2008, 10). However, as Thøgersen points out in Chap. 5, there is little 
direct collaboration between nonprofit schools and the municipalities in which they are located. In other words, indirect government through collaborative governance seems to be limited to the relationship between the private service provider and national public authorities (e.g., through the national system for supervision). The Danish supervision system contrasts sharply with the Swedish system, where it is difficult to detect any form of collaborative governance. Swedish supervision is centralised and carried out by national authorities, and there is little involvement by users or parents. Users and parents may be involved in the Norwegian case, but they are not given any formal rights or obligations comparable to the Danish situation.

To conclude, the basic government model for nonpublic actors within primary and lower secondary education in all three countries appears to be indirect government. There are nevertheless substantial variations with regard to private service providers' freedom to use their own discretion; therefore, the influence of such providers also varies widely. There are also elements of market-based government, where choices made by users determine the composition of the welfare mix. In Denmark, the arrangements for the supervision system also display strong elements of collaborative governance. In this sense, we presume that the government regime can be described as layered. However, the final authority rests with the national authorities who establish the national standards for approval and have the power to revoke this approval.

\section{Nonpublic Producers of Institution-Based Elderly Care $^{15}$}

In this section, we move on to policies on institution-based elderly care. Again, based on detailed analysis of national policy documents such as legislation, instructions, and guidelines and using the models from Table 3.1, we compare the three countries to show how contracts are awarded and coordinated in Denmark, Sweden and Norway.

There is a long tradition of public-sector elderly care in Scandinavian welfare states. The practice of elderly care has changed over time, for example, with regard to the balance between home-based and 
institution-based care. Likewise, attitudes towards the organisation of elderly care are gradually changing as well. For-profit providers of elderly care are no longer a distant possibility, but have become actual practice in many 'marketised' Scandinavian municipalities (Meagher and Szebehely 2012). Elderly care is a municipal responsibility, and each municipality decides how this task will be organised and carried out. The municipalities thus play a decisive role in shaping the welfare mix within elderly care (Ascoli and Ranci 2007). A nonpublic actor that wants to run a publicly financed nursing home is largely reliant on choices made by the municipality. This contrasts with schools, where municipalities have less influence over the welfare mix.

Unfortunately, comparable data on the welfare mix within elderly care in Scandinavia are scarce. Nevertheless, Marta Szebehely and Gabrielle Meagher (2012, 244-245) presented some estimates, and Karl Henrik Sivesind (2016; Chapter 2 in this book) described the changes in the welfare mix in Scandinavia based on different kinds of statistical data. ${ }^{16}$ They all concluded that most care services are still provided by the public sector, but that there are some significant differences between each country: The nonprofit sector plays an important role in elderly care in Denmark and, to a minor extent, in Norway; whereas Sweden stands out as having a more extensive for-profit sector. In addition, in Sweden (and Finland), 'the growth of its share has been faster and large corporations have a stronger position', according to Szebehely and Meagher (2012, 242).

Individual municipalities usually enter into a contract with private service providers, but there are exceptions. In Denmark, a private care provider can bypass the municipality and obtain the right to provide institution-based care services through a national approval system for so-called 'independent nursing homes' (Danish: friplejeboliger). Under this system, a private provider of independent nursing homes acquires the right to offer a place to persons in need of nursing care. The provider must fulfil a number of predefined criteria in order to acquire this right. When the user's need for care is assessed and warranted by the municipality, he or she can opt for a place in an independent nursing home. The municipality is then required to enter into a contract with the private provider. Accordingly, a Danish municipality cannot single-handedly decide the 
welfare mix within its boundaries. This arrangement resembles what we find in the school sector: National authorities define the criteria for being approved as a provider. We therefore state that indirect government also exists in elderly care-in this case, a service concession contract. On the basis of in-house case law, Danish municipalities can also enter into agreements with self-owning institutions, which are outside the scope of the Procurement Act and the EU Public Procurement Directive. They can also launch open calls for tenders on institution-based elderly care.

In both Norway and Sweden, the municipalities themselves choose how institution-based elderly care within their borders will be organised (Vabo 2012). In Sweden, a municipality can choose between implementing LOV (The Freedom of Choice Act), using open calls for tenders according to the LOU (Public Procurement Act), or utilising the freedom of action provided by the in-house case law; a Swedish municipality can also choose a combination of these. ${ }^{17}$ However, Swedish national guidelines nevertheless encourage the use of LOV. ${ }^{18}$ In short, this means that users can freely choose between service providers approved by the municipality. The municipality must approve all providers that satisfy the requirements, which are formulated by the municipality itself. The money then follows the patient.

Norwegian national policy documents encourage open calls for tenders, but leave room for restricted competition between nonprofit providers. Norwegian municipalities can also implement free user choice, but this choice is restricted to those providers that have entered into a contract with the municipality on the basis of a framework agreement or the 'money follows the patient' principle.

National policies on the organisation of elderly care and municipal freedom of action are just some of the aspects of our models of government. Another aspect is each actor's discretionary power over the content of cooperation on elderly care. National authorities in all three countries express views on the requirements and conditions for entering into a contract. On the one hand, this includes formal procedures based on the EU Public Procurement Directive and adjacent national legislation. These are largely similar in the three countries. However, policy documents in Denmark - to a much greater extent than in the other two countriesstress that municipalities should find creative solutions. These documents 
emphasise that cooperation between public authorities and private providers can be organised according to a partnership model, rather than as a hierarchical customer-provider relationship (Udbudsportalen 2011, 16). We interpret this as a request for more collaborative governance.

On the other hand, national policies in all three countries also contain essential goals for elderly care. The emphasis on values such as self-determination, dignity and respect for the individual user, which supports the overall aim of active citizenship in welfare services through empowerment and the free choice of the user, constitutes a basic similarity between the three countries. There is nevertheless considerable variation when these values are translated into concrete regulations; that is to say, into 'tools of government'. The extent of discretionary power that rests with the provider clearly varies. In Sweden, so-called 'national evaluation' criteria include very detailed indicators, which are used as a starting point for national supervision of municipal care. National authorities also recommend that municipalities use these indicators in their supervision and specification of requirements for private providers.

All three countries have systems for the national supervision of institution-based care, covering all types of providers-public as well as private. The purpose is to ensure that care is carried out in accordance with legislation and other national regulations. This type of national supervision is supplemented by tasks that are assigned to municipalities and providers. The providers, for example, are required to have internal control systems.

The major difference between the countries is the role of the users and their relatives in supervision. Swedish national guidelines seem to devote less attention to these user groups as active citizens than do their Danish and Norwegian counterparts. National authorities in Sweden put much less emphasis on the institutionalised influence, participation and empowerment of users (e.g., user boards). Instead, Swedish guidelines tend to focus on informal day-to-day influence: for example, on the daily routines in nursing homes. Furthermore, there are no concrete recommendations on providing information to users, even though this topic has received considerable attention in many of the reports issued by Swedish national authorities. Only Danish municipalities and providers have a statutory obligation to inform potential users. Norwegian 
guidelines emphasise user involvement, but little is said about the information on which this involvement should be based. Norwegian municipalities are not obliged to provide easy access to relevant information in a way comparable to Danish requirements.

Generally speaking, we find that Scandinavian national authorities do not lay down clear regulations on the organisation of elderly care or the conditions for private providers. Thus, on the one hand, municipalities have considerable leeway in determining the welfare mix. On the other hand, national authorities express quite detailed expectations through legislation, regulations and supervision. In the case of Norway, Signy Vabo found that national steering of elderly care has increased over time. However, this steering focuses on processes instead of content or results. The increased steering is relatively 'soft' and does not interfere in any major way with municipal priorities (Vabo 2012, 122). This indicates a relatively large degree of discretion.

In light of the analytical models listed in Table 3.1, we assume several options to be available for the organisation of public-private collaboration on elderly care in the three countries. First, Danish and Swedish municipalities can practise direct government on the basis of in-house case law. Second, municipalities can practise indirect government through specifications in their call for tenders (all countries) and LOV announcements (Sweden). Third, Danish users (and Norwegian and Swedish users, if their municipalities allow it) can also exercise influence by choosing from among the approved providers. ${ }^{19}$ In this respect, there is also an element of market-based organisation in the governing of elderly care.

In our discussion of the analytical framework, we pointed out that the use of different models of government within a single policy area can be described as layered government, meaning that the welfare mix is organised through several steps. In both Denmark and Sweden (but less so in Norway), the national authorities encourage municipalities to facilitate the free choice of users between pre-selected service providers. In this way, the idea of market-based organisation is combined with elements of direct or indirect government: The public sector facilitates consumer empowerment by means of contracts with or the approval of certain 
service providers. However, the organisation of areas of welfare service may also reflect parallel government regimes. That is to say, we find that national policy allows welfare mix to be organised in several distinct ways, implying that private service providers may have more than one alternative to become providers of publicly funded welfare services. This is seen in the Danish case, where private providers of independent nursing homes can be approved at the national level-bypassing the municipalities-and then enter the municipal welfare mix through user choice. This is also seen in Sweden, where it can be argued that the LOV has created parallel systems. Furthermore, private providers find yet another way into the municipal welfare mix in Denmark and Sweden: The municipality can enter into an agreement with a private provider based on the criterion of contracting entity and the criterion of control. This can be described as an extended form of in-house service production. Here, public authorities can supervise the private providers on equal terms with municipal providers.

\section{Discussion: A Unified Scandinavian Model?}

In this chapter, we have shown how national authorities in Denmark, Norway and Sweden approach the use of private providers-for-profit as well as nonprofit - in primary and lower secondary education, and in institution-based elderly care. All three countries stress elements of active citizenship, having designated a diverse spectrum of services, adaptations to the needs of the users, and user participation as central goals for their publicly financed welfare services. To reach these goals, they have looked for new ways to organise and direct the provision of welfare services. Alternatives to the traditional model, where the public sector both finances and provides the services, have been in demand. This served as the backdrop for our discussion of the interaction between the public sector and private welfare providers, especially the use of contracts. As a tool of government, contracts may reflect a direct, indirect or disconnected model of government. 
The EU Public Procurement Directive is relevant in this context because it limits the latitude for national policymaking. All three countries have bound themselves to follow the Directive through EU membership (Denmark and Sweden) or the EEA agreement (Norway). Although standardisation is the general purpose, the Directive specifies several tendering procedures and types of contracts that fall outside of its scope. Accordingly, the Directive allows latitude for national policymaking. In conclusion, we find that the EU Directive does not itself decide whether welfare services will be provided through direct, indirect or disconnected government, nor does it unambiguously standardise the welfare mix across countries. However, even though the EU allows national latitude (Nyberg 2013; Directive 2014/23/EU, (53) page 10), it is clear that this latitude is approached and utilised differently in each Scandinavian country.

In both Sweden and Denmark, national policy documents define leeway for public authorities, which goes beyond the most detailed regulations of the EU Directive as well as national public procurement rules. This is done by using the in-house argument within elderly care, and by awarding contracts to approved providers within both schools and elderly care. Norway also has a system with approved private schools, but uses neither the in-house argument nor contracts to approved providers within elderly care. Instead, Norway has practised an exception to the public procurement regulations, which applies to contracts with nonprofit providers of health and social services (including elderly care). However, although this nationally defined exception is important, it does not alter the general impression: Norwegian authorities largely consider the issue of private welfare providers a question of public procurement. Accordingly, the EU Directive establishes an important framework for the welfare service provision.

The overall impression is one of considerable similarity between Danish, Norwegian and Swedish national policies on the welfare mix, within both education and elderly care. As we have seen, the share of welfare services produced by private providers nevertheless varies considerably, and there are some differences that may contribute towards explaining this variation. The national frameworks for interaction 
between the public payer and the private provider vary substantially, especially concerning the distribution of discretionary power.

We conclude that all three countries fall under the indirect government model of Table 3.1 with regard to the school sector, where public authorities govern by means of predefined requirements for approving private schools, as well as by supervision. Private providers are neither governed directly nor free from any kind of control. Furthermore, there are elements of market-based organisation in the school sector, because users have the right to choose their schools. However, this choice is limited to publicly approved schools. The 'market' is thus a quasi-market, only partially disconnected from public steering.

Unlike the school sector, we find that the national policies for institution-based elderly care provide neither a unified Scandinavian model nor a single model within each country. Rather, the case of elderly care demonstrates that national policies can provide leeway for a combination of different models of government. Public procurement regulations and more or less detailed requirements for the content of the services are highlighted in policy documents in all three countries, but this is not the only type of indirect government that national policies allow. The municipalities themselves can largely choose their own tools of governance, but there are some differences between the countries.

In Denmark, the opportunity to enter into agreements with providers shows how public authorities can govern private providers directly, in a similar way as in-house providers. Furthermore, the Danish and Swedish cases clearly show how organisational and legal policy tools at the national level can facilitate disconnected government based on user choice. Strictly speaking, we regard this as a quasi-market-based organisation, since users can choose between approved institutions (as in the school sector). An important difference is that the Swedish users get a voucher-the money follows the care-needing elderly—while the Danish users can basically choose only between municipal nursing homes or nursing homes that have an agreement with the municipality. If a Danish user wants a place in an independent nursing home, the private provider of that nursing home has the right to refuse. Accordingly, private providers of independent nursing homes have the same discretionary power as Danish private schools. This will be discussed below. 
Moreover, the Danish national system for the approval of independent nursing homes shows how government models within elderly care are not only layered, but also parallel. Sweden also has a parallel system, but unlike their Danish counterparts, Swedish municipalities are not at the mercy of a national approval system. Swedish municipalities decide for themselves whether to implement the LOV, which implies a local approval system and user choice.

When we refer to parallel models of government, we mean that private providers can enter into the welfare mix in different ways, and that the public sector can use different tools of government. This is not just a layered system, but a combination of parallel systems with different logics (such as competition, approval and internal organisation) and different regulation systems. We believe that parallel government models can be a key to diversity in welfare services. Through these parallel systems, it could be possible to encourage and support different purposes and actors in the production of welfare services. If a single model limits the possibility of promoting a certain welfare mix, a combination of models may prove more flexible.

We must, however, emphasise that a diverse welfare mix not only depends on the country's model of government, but also on the discretionary power of private actors. To what extent are they free to define the values and goals for their own welfare service production? If these values and goals are defined by narrow national standards, a diverse supply of services will be improbable. Consequently, it may also be difficult to achieve a central element of active citizenship: the possibility to choose between a broad range of different services. Phillips and Smith $(2011,22)$ maintained that national regulations may be an important incentive for cooperation with nonprofit organisations. However, nonprofit actors are often motivated by their ideals. They will hardly operate in a field which is regulated in detail if doing so means compromising their basic values.

Our account of the national frameworks within education and elderly care shows that the discretionary power given to private providers varies considerably. The greatest extent of discretionary power over non-economic issues is given to Danish service providers. There is no doubt that Danish national policies stand out by facilitating diversity, as 
they show more openness towards the (non-commercial) values of private providers. More concretely, Danish private providers are given more discretion with regard to their service production and its underlying values. The criteria for approving Danish private schools not only concerns quality and economy, but also whether the schools ensure that their values are communicated and upheld. Moreover, Danish providers of private schools and independent nursing homes can use more discretion in their selection of users; in other words, they can refuse admission. The differences between the countries are smaller with respect to elderly care, except that Sweden stands out with a more detailed control regime that indirectly restricts the discretionary power of the providers and encourages a for-profit perspective in the welfare mix. This is also the case within primary and lower secondary education,, where Swedish private owners - unlike their Danish and Norwegian counterparts—are allowed to make profits. With regard to payoff discretion, Swedish providers thus hold a unique position. The for-profit aspect is a more general trait of the Swedish welfare mix.

\section{Concluding Remarks: The Role of Politics}

There are thus both similarities and differences between the Scandinavian countries when it comes to national regulation of private providers within education and elderly care. Even though it may be debated whether the differences or similarities are the most conspicuous, there are certainly some distinctions and nuances that separate the models of welfare government in the three countries. Our analyses and discussion indicate that variations in these models may explain some-but not allof the differences in the welfare mix. However, this leaves us with the question of why these government models differ. Politics may be an underlying factor that explains either the differences in the governance of welfare production or the differences in the actual welfare mix —or both.

One question is whether the party composition of national governments has affected national policies. This is clearly of importance in light of the changes that have taken place in Sweden. Reforms were initiated by the centre-right Bildt government (1991-1994), and further reforms, 
such as the User Choice Act, were implemented by the centre-right Reinfeldt government (2006-2014). Sweden is perhaps the foremost example of the impact of politics on the welfare mix - and the political will to change. During the 1990s, 'freedom of choice' and 'competition' were the leading slogans of Swedish politics. This led to several reforms, including in education and elderly care. Accordingly, Sweden went from being a welfare state where the public sector provided almost all welfare services, to a welfare society where the role of for-profit providers increased and the users themselves obtained the opportunity to affect the welfare mix through their choice of providers.

The impact of changing governments can also be seen in Norway: The centre-right Bondevik II government (2001-2005) made it easier to establish nonpublic schools which were neither religious nor pedagogical alternatives. This change was reversed by the centre-left Stoltenberg II government (2005-2013), while this policy once again was partly liberalised by the right-wing Solberg government (2013-). However, there is still no distribution of profits from state-funding in schools and the rigid requirements for approval have been maintained.

Although party politics matter, they cannot explain policy differences between Scandinavian countries. For example, the Norwegian Solberg government has not allowed owners to make profits from nonpublic schools. On the contrary, during the 2013 Norwegian election campaign, all parties described the Swedish situation as undesirable. The Norwegian Left accused the Right of wanting to introduce the Swedish policies in Norway, whereas the Norwegian Right emphasised the differences between themselves and their Swedish counterparts. Moreover, the Swedish policy shift is not just a matter of changing governments. Hicks (2015), for example, emphasised continuity between the social democratic and centre-right governments with regard to school policy: The reforms that led to an increasing for-profit sector were to a large extent accepted by the social democrats.

The Danish case also illustrates how party politics can be of limited importance. Since 2001, right-wing parties have been in government most of the time (2001-2011 and 2015-). However, there has been no major marketisation reform. The Danish case thus highlights the importance of national historical traditions. The country has a 
long-standing tradition of independent nonprofit schools, which influences the current political discourse. This tradition dates back to the middle of the 1800s, building on the work and philosophy of N.F.S Grundtvig. Today, there is a wide ideological range of nonprofit alternatives in Denmark-from left-wing alternative movements to Christians and liberals. Each of these groups has political allies, and this leads to cross-party consensus on the importance of the nonprofit sector. Although the nonprofit sector is much smaller in Norway than in Denmark, elements of this situation are found in Norway as well. In the Norwegian case, the pivotal position of the Christian People's Party and the Liberal Party appears to be important. These parties have traditionally been sceptical of the marketisation of education and elderly care; their priority has been to protect nonprofit institutions from the effects of marketisation. In Sweden, in contrast, such barriers to the development of for-profit alternatives appear to be absent.

In short, there is a strong element of path dependency which limits the options that have been discussed and thereby also alternative developmental trajectories. This observation is in accordance with the predominant literature on welfare states, in which one main argument has been that 'history and politics matter' (Arts and Gelissen 2010, 570). The historical development-described by Sivesind in Chapter 2-can to some extent explain the policies today. Where nonprofit alternatives were weak initially, the discourse on alternatives, user choice, etc., now tends to focus on state versus market-as we have seen in Sweden. When a nonprofit sector of some size exists, it tends to mobilise its political supporters and thereby displace the left-right discourse, as we have seen in Denmark.

\section{Notes}

1. We use the term 'collaborative governance' as synonymous with related concepts, such as 'governance network'.

2. Article 1 in Directive 2004/18/EC.

3. Article 2 in Directive 2004/18/EC.

4. A fourth category is design contests, but it is not relevant for primary education and institution-based elderly care (Article 1(11)(e)). 
5. In Article 1(4), a service concession is described as 'a contract of the same type as a public service contract except for the fact that the consideration for the provision of services consists either solely in the right to exploit the service or in this right together with payment'.

6. The act and regulations in force as per 2014 is the act from 1999 (LOV1999-07-16-69) and the regulations (FOR-2006-04-07-402) that came into force in January 2007 (FAD 2013:9).

7. LBK nr 1410 af $07 / 12 / 2007$ with changes made through LOV nr 618 af 14/06/2011 $₫ 2$ and LOV nr 1234 af 18/12/2012 $\$ 1$.

8. According to changes made through the law, LOV nr 1234 af $18 / 12 / 2012 \$ 1$, 'the contracting authorities no longer have ... a duty to follow the regulation of the Procurement Act for announcement of the Annex II B-services independent of the contract value. However, the contracting authorities are still committed to follow some of the regulations in the EU Directive if the contract value is higher than the threshold amounts defined for EU tenders' (Udbudsportalen 2014b, our translation). For more information, please see Konkurrence-og Forbrugerstyrelsen (2013).

9. Sweden implemented the EU Directive for the first time through a 1995 revision of the 1992 Public Procurement Act (Swedish: Lag om offentlig upphandling-LOU) (see SFS 1995:704, SFS 1992, 1528). The act in force per 2014 is Lag om offentlig upphandling (SFS 2007, 1091) from 2008. Some amendments to the act have later been made, which correspond to changes made in Denmark and Norway.

10. The European Commission explains the main differences between a concession and a public contract, and the reasons for having separate legislation, in this way (European Commission 2014, 3): 'Concessions have specific features compared to public contracts which justify a special and more flexible set of rules for their award. Concessions are typically high-value, complex and long-term contracts which require appropriate flexibility during the award procedure to ensure the best possible outcome. Specific legislation for concessions helps distinguish between the rules applicable to concessions and the more detailed ones applicable to public contracts and therefore makes them simpler to use'.

11. In the MEMO 14/19 (page 3), the European Commission concludes that ' $[\mathrm{n}] \mathrm{o}$ public authorities in each Member State retain the possibility to define and enforce public service obligations and to organise the provision of services of general interest. By imposing public service 
obligations, public authorities remain free to define the characteristics of the service to be provided, including any conditions regarding the quality of the service, in order to pursue their public policy objectives'.

12. This section is based on our detailed analyses of the national policies on schools and elderly care in Norway, Denmark and Sweden (Segaard 2015).

13. The field of private schools is regulated by national legislation, e.g. Friskoleloven in Denmark (LBK nr 917 af 13/08/2014), Skollag in Sweden (SFS 2010: 800), and Privatskoleloven in Norway (Utdanningsdirektoratet (2014), as well as several supplementary policy documents (regulations, instructions, guidelines, etc.) Please see Segaard (2015) for further references to such policy documents.

14. Even though Swedish private schools are basically fully financed, the school owner bears the economic risk. This is because the funding depends on the number of pupils, not what it actually costs to run the school. The school owner is given the right to run a school when it is approved, but it is not guaranteed that the school will attract a sufficient number of pupils.

15. The field of private institution-based elderly care is regulated by national legislation and regulations: in Sweden, e.g. Lag om offentlig upphandling (LOU 2007:1091) and Lag om valfrihetssystem (LOV 2008:962); in Norway, e.g. Helsetilsynsloven (LOV-1984-03-30-15), Helse- og omsorgstjenesteloven (LOV-2011-06-24-30), Forskrift for sykehjem og boform for heldøgns omsorg og pleie (FOR-1988-11-14-932) and Internkontrollforskriften (FOR-1996-12-06-1127); and in Denmark, e.g. Friplejeboligloven (LBK nr 897 af 17/08/2011) and Serviceloven (LBK nr 1023 af 23/09/2014), as well as several supplementary policy documents (instructions, guidelines etc.). Please see Segaard (2015) for further references to such policy documents.

16. For details, please also see Szebehely (2011), Thøgersen (2013) and Statistics Norway (2015).

17. A national system for registration of social service providers in general and providers of institution-based elderly care in particular exists in Sweden, but it is not comparable to the Danish national authorisation system.

18. Unlike the municipalities, Swedish counties are required to implement LOV (Upphandlingsmyndigheten 2015).

19. Unlike the Swedish case, Danish users are not given a voucher which could be used to choose any provider. 


\section{References}

Arts, Wil A., and John Gelissen. 2010. Models of the welfare state. In The Oxford Handbook of the Welfare State, eds. Francis G. Castles, Stephan Leibfried, Jand Lewis, Herbert Obinger, and Christopher Pierson, 569-583. Oxford: Oxford University Press.

Ascoli, Ugo, and Costanzo Ranci (eds.). 2007. Dilemmas of the Welfare Mix: The New Structure of Welfare in an Era of Privatization. New York: Kluwer.

BEK nr 415 af 22/06/1993. Bekendtgørelse om samordning affremgangsmåderne ved indgåelse af kontrakter om offentlige indkøb af tjenesteydelser i De Europæiske Fællesskaber (Tjenesteydelsesbekendtgørelsen). https://www. retsinformation.dk/Forms/R0710.aspx?id=64623\&exp=1. Accessed 4 Nov 2015.

BEK nr 712 af 15/06/2011. Bekendtgørelse om fremgangsmåderne ved indgåelse af offentlige vareindkøbskontrakter, offentlige tjenesteydelseskontrakter og offentlige bygge- og anlægskontrakter. https://www.retsinformation.dk/forms/ r0710. aspx?id=137281\&exp=1. Accessed 4 Nov 2015.

CURIA (not dated). Case C-274/09. http://curia.europa.eu/juris/document/docu ment_print.jsf;jsessionid=9ea7d0f130d56f74bc2654fa42a6ba87a7b896d7c1 ed.e34KaxiLc3eQc40LaxqMbN4Oc38Oe0?doclang=EN\&text=\&pageIndex= $0 \&$ part $=1 \&$ mode $=$ DOC $\&$ docid $=124672 \&$ occ $=$ first $\&$ dir $=\&$ cid $=180472$. Accessed 9 Nov 2015.

Difi. 2014. Likevel unntak for ideelle under nye EU-regler? http://www.anskaffelser. no/nyhet/2014-06-11/likevel-unntak-ideelle-under-nye-eu-regler. Accessed 15 Oct 2014.

Directive 2004/18/EC. Rules on public works contracts, public supply contracts and public service contracts, applicable until 2016. http://eur-lex.europa.eu/ legal-content/EN/TXT/PDF/?uri=CELEX:32004L0018\&from=EN. Accessed 25 Aug 2015.

Directive 2014/23/EU. Directive 2014/23/EU of the European Parliament and of the Council of 26 February 2014 on the award of concession contracts. http://eur-lex.europa.eu/legal-content/EN/TXT/?uri=celex:32014L0023. Accessed 26 Oct 2015.

Directive 2014/24/EU. Directive 2014/24/EU of the European Parliament and of the Council of 26 February 2014 on public procurement and repealing Directive 2004/18/EC. http://eur-lex.europa.eu/legal-content/DA/LSU/? uri=CELEX:32014L0024. Accessed 26 Oct 2015. 
Donahue, John D., and Richard J. Zeckhauser. 2006. Public-Private Collaboration. In The Oxford Handbook of Public Policy, eds. Michal Moran, Martin Rein, and Robert E. Goodin, 496-525. Oxford: Oxford University Press.

Ervasti, Heikki, Torben Fridberg, Mikael Hjerm, Olli Kangas, and Kristen Ringdal. 2008. The Nordic Model. In Nordic Social Attitudes in a European Perspective, eds. Heikki Ervasti, Torben Fridberg, Mikael Hjerm, and Kristen Ringdal, 1-21. Cheltenham: Edward Elgar.

European Commission. 2014. Directive of the European Parliament and of the Council on the award of Concession Contracts - Frequently Asked Questions. MEMO/14/19. Brussels. http://europa.eu/rapid/press-release_ MEMO-14-19_en.htm. Accessed 4 Nov 2015.

Eurostat. 2012. Key Data on Education in Europe 2012. Brussels: Education, Audiovisual and Culture Executive Agency. http://ec.europa.eu/ eurostat/documents/3217494/5741409/978-92-9201-242-7-EN.PDF/ d0dcb0da-5c52-4b33-becb-027f05e1651f. Accessed 24 June 2015.

FOR-1988-11-14-932. Forskrift for sykehjem og boform for heldøgns omsorg og pleie. Last changed 01.07.2013. https://lovdata.no/dokument/ SF/forskrift/1988-11-14-932. Accessed 11 Mar 2015.

FOR-1996-12-06-1127. Forskrift om systematisk helse-, miljø- og sikkerhetsarbeid i virksomheter (Internkontrollforskriften). Last changed 01.07.2013. https://lovdata.no/dokument/SF/forskrift/1996-12-06-1127. Accessed 11 Mar 2015.

FOR-2006-04-07-402. Forskrift om offentlige anskaffelser. http://lovdata. no/dokument/SF/forskrift/2006-04-07-402. Accessed 23 Apr 2015.

Fornyings- og administrasjonsdepartementet (FAD). 2006. Veileder til reglene om offentlige anskaffelser. http:/www.regjeringen.no/upload/kilde/fad/bro/ 2006/0006/ddd/pdfv/299663-veileder_reglene_offentlige_anskaffelser_rev. pdf. Accessed 13 May 2014.

Fornyings- og administrasjonsdepartementet (FAD). 2013. Veileder til reglene om offentlige anskaffelser. http://www.regjeringen.no/upload/FAD/Vedlegg/ Konkurransepolitikk/Anskaffelsesveilderer_2013.pdf. Accessed 8 May 2014. Hicks, Timothy. 2015. Inequality, marketisation and the left: Schools policy in England and Sweden. European Journal of Political Research 54 (2): 326-342.

Konkurransepolitisk avdeling. 2005. Forskrift om offentlige anskaffelser og ideelle organisasjoner. (Letter addressed to Vogt and Wiig Trondheim AS Advokatfirma dated 14.04.2005). http://www.regjeringen.no/upload/ $\mathrm{kilde} / \mathrm{mod} / \mathrm{red} / 2004 / 0001 / \mathrm{ddd} / \mathrm{pdfv} / 243678$-vogt_og_wiig.pdf. Accessed 13 May 2014. 
Konkurransepolitisk avdeling. 2008. Anskaffelsesregelverket ved kjøp av barnevernstjenester fra private aktører. (Letter addressed to Ministry of Children and Equality dated 21.01.2008). http://www.regjeringen.no/upload/FAD/ Vedlegg/Konkurransepolitikk/Anskaffelser/Fortolkningsuttalelse_ansk_ barnevern.pdf. Accessed 23 Apr 2015.

Konkurrence- og Forbrugerstyrelsen. 2013. Køb af B-tjenesteydelser. Vejledning. Valby: Konkurrence- og Forbrugerstyrelsen. http://www.kfst. $\mathrm{dk} / \sim /$ media/KFST/Offentlig\%20konkurrence/Regler\%20og\% 20vejledninger/Vejledninger/Vejledning\%20om\%20koeb\%20af\% 20Btjenesteydelser\%203\%20september\%202013\%20FINAL.pdf. Accessed 25 Aug 2014.

Konkurrencestyrelsen. 2010. In-house begrebets betydning for kommunal aftaleindgåelse med selvejende institutioner. http://www.udbudsportalen.dk/ ImageVaultFiles/id_41818/cf_202/Vejledende_udtalelse_om_In-house_ begrebets_betydni.PDF. Accessed 17 Mar 2015.

Konkurrensverket. 2014. Upphandlingsreglerna - en introduktion. http://www. konkurrensverket.se/globalassets/publikationer/informationsmaterial/ upphandlingsreglerna-en-introduktion.pdf. Accessed 20 Apr 2015.

Kronbøl, Trine. 2015. Phone call with Signe Bock Segaard 16.03.2015. Kronbøl works at the Udbudsportalen.

LBK nr 1023 af 23/09/2014. Bekendtgørelse af lov om social service (Serviceloven). https://www.retsinformation.dk/Forms/R0710.aspx?id= 164215. Accessed 18 Aug 2016.

LBK nr 1410 af 07/12/2007. Bekendtgørelse af lov om indhentning af tilbud på visse offentlige og offentligt støttede kontrakter. https://www.retsinformation. $\mathrm{dk} /$ forms/r0710.aspx?id=113858. Accessed 26 Oct 2015.

LBK nr 897 af 17/08/2011. Bekendtgørelse af lov om friplejeboliger (Friplejeboligloven). https://www.retsinformation.dk/Forms/R0710.aspx?id= 136448. Accessed 19 Mar 2015.

LBK nr 917 af 13/08/2014. Friskoleloven. https://www.retsinformation. $\mathrm{dk} /$ forms/r0710.aspx?id=164404. Accessed 19 Nov 2014.

LOU 2007:1091. Lag om offentlig upphandling. http://www.riksdagen.se/sv/ Dokument-Lagar/Lagar/Svenskforfattningssamling/_sfs-2007-1091/. Accessed 8 Apr 2015.

LOV 2008:962. Lag om valfrihetssystem. http://www.riksdagen.se/sv/ Dokument-Lagar/Lagar/Svenskforfattningssamling/Lag-2008962-omvalfrihetssy_sfs-2008-962/. Accessed 8 Apr 2015. 
LOV nr 1234 af 18/12/2012. Lov om ændring af lov om indhentning af tilbud på visse offentlige og offentligt støttede kontrakter og lov om kommuners udførelse af opgaver for andre offentlige myndigheder og kommuners og regioners deltagelse i selskaber. https://www.retsinformation.dk/forms/r0710. aspx?id=144417. Accessed 26 Oct 2015.

LOV nr 618 af 14/06/2011. Lov om ændring af lov om håndhævelse af udbudsreglerne m.v. og lov om indhentning af tilbud på visse offentlige og offentligt støttede kontrakter. https://www.retsinformation.dk/forms/r0710. aspx?id=137689. Accessed 26 Oct 2015.

LOV-1984-03-30-15. Lov om statlig tilsyn med helse- og omsorgstjenesten m. m. (helsetilsynsloven). Last changed 1 July 2014. https://lovdata. no/dokument/NL/lov/1984-03-30-15. Accessed 12 Mar 2015.

LOV-1999-07-16-69. Lov om offentlige anskaffelser (anskaffelsesloven). https:// lovdata.no/dokument/NL/lov/1999-07-16-69. Accessed 26 Oct 2015.

LOV-2011-06-24-30. Helse- og omsorgstjenesteloven.

Meagher, Gabrielle, and Marta Szebehely (eds.). 2012. Marketisation in Nordic eldercare: a research report on legislation, oversight, extent and consequences. Stockholm: Stockholm University.

Nyberg, Linda. 2013. Vad får staten göra? - EU:s statsstödsregler och svensk förvaltningspolitik. In När förvaltning blir business, eds. Linda Rönnberg, Urban Strandberg, Elin Wihlborg, and Ulrika Winblad, 187-206. Linköping: Linköping University Press.

Ødegård, Anne Mette. 2006. Offentlig innkjøp som regulator. Oslo: Fafo Østforum. http://www.fafo.no/Oestforum/Kunnskapsbase/Publikasjoner/ Oestforum_publikasjoner/art_offanskaff_amo.pdf Accessed 8 May 2014.

Phillips, Susan D., and Steven Rathgeb Smith. 2011. Between Governance and Regulation. Evolving Government-Third Sector Relationships. In Governance and Regulation in the Third Sector. International Perspectives, eds. Susan D. Phillips, and Steven Rathgeb Smith, 1-36. New York: Routledge.

Rose, Lawrence E. 2005. Demokratiteori - forventninger og virkelighet. In Det kommunale laboratorium: Teoretiske perspektiver på lokal politikk og organisering, 2nd ed, eds. Harald Baldersheim, and Lawrence E. Rose, 53-86. Bergen: Fagbokforlaget.

SEC(2011) 1169 final. Commission staff working paper concerning the application of EU public procurement law to relations between contracting authorities ('public-public cooperation'). Brussels: European Commission. 
http://ec.europa.eu/internal_market/publicprocurement/docs/public_ public_cooperation/sec2011_1169_en.pdf. Accessed 27 Oct 2015.

Segaard, Signe Bock. 2015. Skole og eldreomsorg i Skandinavia. Nasjonale foringer for ikke-offentlige aktører. Report 2015:07. Oslo: Institute for Social Research.

Sejersted, Fredrik. 2014. Rettslig vurdering av om unntaket for kjøp av helse- og sosialtjenester fra ideelle organisasjoner kan videreføres. https://www. regjeringen.no/no/aktuelt/Sejersted-rapporten-klar/id765116/. Accessed 25 June 2015.

SFS 1992:1528. Lag om offentlig upphandling. http://www.riksdagen.se/sv/ Dokument-Lagar/Lagar/Svenskforfattningssamling/Lag-19921528-omoffentlig-u_sfs-1992-1528/. Accessed 26 Oct 2015.

SFS 1995:704. Lag om ändring i lagen (1992:1528) om offentlig upphandling. http://www.lagboken.se/Views/Pages/GetFile.ashx?portalId=56\&cat= 24593\&docId=357029\&propId=5. Accessed 26 Oct 2015.

SFS 2007:1091. Lag om offentlig upphandling (LOU). http://www.riksdagen. se/sv/Dokument-Lagar/Lagar/Svenskforfattningssamling/_sfs-2007-1091/. Accessed 8 Apr 2015.

SFS 2010:800. Skollag 2010:800. Svensk författningssamling. http://www. riksdagen.se/sv/Dokument-Lagar/Lagar/Svenskforfattningssamling/Skollag2010800_sfs-2010-800/?bet=2010:800. Accessed 12 Feb 2015.

Sivesind, Karl Henrik. 2016. Endring av fordelingen mellom ideelle, kommersielle og offentlige velferdstjenester i Skandinavia. In Mot en ny skandinavisk velferdsmodell?, ed. Karl Henrik Sivesind, 66-73. Report 2016:01. Oslo: Institute for Social Research.

Sørensen, Eva, and Jacob Torfing. 2008. Introduction: Governance Network Research: Towards a Second Generation. In Theories of Democratic Network Governance, eds. Eva Sørensen, and Jacob Torfing, 1-21. Hampshire: Palgrave Macmillan.

Statistics Norway. (SSB). 2015. Pleie og omsorgstjenester. http://www.ssb. no/pleie. Accessed 9 May 2016.

Szebehely, Marta, and Gabrielle Meagher. 2012. Four Nordic countries - four responses to the international trend of marketization. In Marketisation in Nordic eldercare: a research report on legislation, oversight, extent and consequences, eds. Gabrielle Meagher, and Marta Szebehely, 241-288. Stockholm: Stockholm University.

Szebehely, Marta. 2011. Insatser för äldre och funktionshindrade i privat regi. In Konkurrensens konsekvenser. Vad händer med svensk välfärd?, ed. Laura Hartman, 215-257. Stockholm: SNS Förlag. 
The Norwegian Government. 2006. Gjennomgang av den særnorske delen av regelverket om offentlige anskaffelse - mandat for offentlig utredningsutvalg. http://www.regjeringen.no/upload/FAD/Vedlegg/Konkurransepolitikk/ Anskaffelser/Anskaffelser_utvalg_mandat.pdf. Accessed 13 May 2014.

The Swedish Riksdag. 2012. Betänkande 2011/12:FiU42. Offentlig upphandling från eget företag. http://www.riksdagen.se/sv/Dokument-Lagar/ Utskottens-dokument/Betankanden/Arenden/201112/FiU42/. Accessed 17 Mar 2015.

Thøgersen, Malene. 2013. Selvejende institutioner i Danmark. Institutionernes udvikling, udbredelse og karakter på udvalgte samfundsområder. Working paper 1, 2013. Aalborg: Netværk for forskning i Civilsamfund og Frivillighed. http://www.cifri.dk/Webnodes/da/Files/Arbejdsnotater/ Selvejende+institutioner+-+01+2013.pdf. Accessed 9 May 2016.

Udbudsportalen. 2011. Vejledning i udbud af drift af plejecentre. February 2011. København: Udbudsportalen.

Udbudsportalen. 2014a. Det klassiske udbudsdirektiv. http://www. udbudsportalen.dk/Ret-og-regler/Direktiver-love-og-regler/Udbudsregler/ Det-klassiske-udbudsdirektiv/. Accessed 25 Aug 2014.

Udbudsportalen. 2014b. Køb af B-tjenesteydelser. http://www.udbudsportalen. $\mathrm{dk} /$ Ret-og-regler/Direktiver-love-og-regler/Udbudsregler/TilbudslovenDanske-regler-for-udbud/Ophavelse-af-annonceringspligten-for-bilag-II-Btjenesteydelser/. Accessed 25 Aug 2014.

Udbudsportalen. 2015. In-house begrebets betydning for kommunal aftaleindgåelse med selvejende institutioner. http://www.udbudsportalen. $\mathrm{dk} /$ Vejledninger/Oficielle-vejledninger-om-udbud/Konkurrencestyrelsensvejledende-udtalelse-om-in-house-begrebets-betydning-for-kommunalaftaleindgaelse-med-selvejende-institutioner/. Accessed 17 Mar 2015.

Udbudsrådet. 2012. Offentlig-privat samarbejde i Danmark og Sverige. Valby: Udbudsrådet. http://www.opiguide.dk/media/49156/Analyse_-_Offentligprivat_samarbejde_i_Danmark_og_Sverige.pdf. Accessed 03 Sep 2015.

Upphandlingsmyndigheten. 2015. Om LOV. Valgfrihetswebben. https:// www.valfrihetswebben.se/om-lov.aspx. Accessed 9 Dec 2015.

Utdanningsdirektoratet. 2014. Tolkning av privatskoleloven med forskrifter. http://www.udir.no/Regelverk/Private-skoler/Regelverk-for-private-skoler-/ Tolkning-av-privatskoleloven-med-forskrifter/. Accessed on 6 Nov 2014. Vabo, Signy Irene. 2012. Tiltakende statlig styring av kommunesektoren - også på eldreområdet? In Det norske flernivådemokratiet, eds. Marit Reitan, Jo Saglie, and Eivind Smith, 97-135. Oslo: Abstrakt forlag. 


\section{Authors' Biography}

Signe Bock Segaard is a senior research fellow at the Institute for Social Research, Oslo, Norway. Her main research interests include public administration and politics, welfare policy, and third sector, local elections and local democracy, as well as political behaviour and communication. Her publications include a coedited volume on social capital in Norway, as well as articles in Journal of Elections, Public Opinion \& Parties; Nordicom Review; Information Polity; and Scandinavian Journal of Public Administration, among others. She is currently project manager on the EU-funded research project 'The Contribution of the Third Sector to Europe's Socio-economic Development' and participates in several research projects on Norwegian local government and politics and welfare mix.

Jo Saglie is Research Professor at the Institute for Social Research, Oslo, Norway. His main research interests include party organisations and intra-party democracy, local elections and local democracy, as well as indigenous politics. His publications include the coedited volume Indigenous Politics: Institutions, Representation, Mobilisation; as well as articles in Journal of Elections, Public Opinion \& Parties; Local Government Studies; Regional and Federal Studies; and West European Politics; among others. He is currently directing the Norwegian Local Election Study and the Norwegian Sámi Parliament Election Study, and he participates in several research projects on Norwegian local government and politics. 
Open Access This chapter is licensed under the terms of the Creative Commons Attribution 4.0 International License (http://creativecommons.org/licenses/by/ $4.0 /$ ), which permits use, sharing, adaptation, distribution and reproduction in any medium or format, as long as you give appropriate credit to the original author(s) and the source, provide a link to the Creative Commons license and indicate if changes were made.

The images or other third party material in this chapter are included in the chapter's Creative Commons license, unless indicated otherwise in a credit line to the material. If material is not included in the chapter's Creative Commons license and your intended use is not permitted by statutory regulation or exceeds the permitted use, you will need to obtain permission directly from the copyright holder.

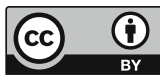

